A number of critics, particularly in the developing world, have addressed both concepts of GATS. On the one hand, they would prefer education to be excluded from GATS altogether. If education is to be dealt with at all in GATS, they call for a much more serious approach to the substance of education, not just its trade aspects. On the other hand, many critics feel that the proper arenas for regulating the global education system consist of the specialized international agencies in the field-UNESCO, in particular. In our view, UNESCO represents an important partner in securing the necessary base for future development and regulation of transborder trade in education services. OECD is another, and Norway has provided a lot of political and financial support to the joint efforts of the two organizations. The primary example involves the development of international guidelines for quality assurance that will be finalized during 2005 , for which Norway has chaired the working group.

UNESCO represents an important partner in
securing the necessary base for future develop-
ment and regulation of transborder trade in
education services. OECD is another, and
Norway has provided a lot of political and
financial support to the joint efforts of the two
organizations.

Even so, compared to the binding legal obligations of GATS, the recommendations and guidelines of UNESCO and OECD constitute much blunter instruments. Given the commercial scale and methods of the education market, the Norwegian position is that enforceable legal safeguards must comprise the most rigorous kind of regulation and that GATS offers a suitable framework. That said, international forums such as UNESCO and OECD, professional associations, NGOs, and academic institutions should have an expanded, not a reduced, role in the future development of a global education system that benefits all.

\section{How Can We All Help?}

Herein lies an important responsibility. While the details of WTO negotiations will probably continue to be clouded in secrecy, vigorous informed debate, research, and academic discourse on education trade issues will carry significant weight and influence decision makers. Perhaps education is too serious a matter to be left to governments alone.

\section{The Rise and Fall of Transnational Higher Education in Singapore}

\section{RICHARD GARRETT}

Richard Garrett is deputy director at the Observatory on Borderless Higher Education, London. Address: Observatory on Borderless Higher Education, 36 Gordon Square, London WC1H OPF, UK. E-mail: r.garrett@obhe.ac.uk.

Tn January 2005, the Singapore minister of education, 1 Tharman Shanmugaratnam, announced a number of new initiatives. These included raising the participation rate by 2010 in the country's three domestic universities by almost 20 percent (to 25 percent of the school-leaving cohort), creating a national open university, and offering university status to selected private institutions. One of the first private institutions in line for university title is the Singapore Institute of Management (SIM). Singapore remains one of the largest markets for transnational higher education in the world and is a particularly important market for Australian and U.K. universities. Leading private institutions, such as SIM, are key local partners and have been drawn to foreign partnerships as a way of offering degrees. The latest announcements may be further evidence of the government's desire to reduce dependence on foreign higher education.

\section{Growth of Transnational Higher Education}

Considering these developments, what are the implications for transnational higher education in Singapore? Extrapolating from the 2000 Singapore census, it is clear that Singapore has an aging population. The current 20-to-24-year age group is the smallest in 30 years (and a full third lower than the peak in the mid-1980s). The school-leaving cohort will rise again over the next five years, peaking around 2010, before falling back. The mid-1980s school-leaver boom saw the beginnings of transnational higher education in Singapore. The government was keen to expand access to higher education but could not grow domestic capacity fast enough. So despite a period of steady cohort decline post-1985, the transnational market in Singapore expanded significantly due to an increase in tertiary participation of the age cohort from 8 percent in I9 85 to I5 percent in 1990. Participation now stands at around 45 percent. This massive expansion has only been possible through foreign provision, whether studying abroad or transnational provision. But while transnational activity was viewed as a way to stem study abroad rates and to mentor local institutions, the long-term aim was greater self-sufficiency.

In 2003, Singapore's domestic universities enrolled around 40,000 students and the polytechnics around 56,000. According to the Singapore Department of Statistics, in 2003 around I70 private tertiary providers in Singapore enrolled 
119,000 students. Of those, 140 offered programs in collaboration with foreign institutions and enrolled 89,000 students in such programs (75 percent of the total). This shows the importance of transnational provision in Singapore, but all figures include students of all ages and international as well as domestic students, making an estimate of relative school-leaver participation difficult. What is certain is that new private universities and the new open university will be chasing many of the students currently on transnational programs from foreign universities. Perhaps two new foreign universities are to be established in Singapore, University of New South Wales from Australia and University of Warwick from the United Kingdom (the latter still to be agreed). This is on top of a number of existing independent foreign campuses, such as INSEAD and the University of Chicago Graduate School of Business. While these institutions (particularly the University of New South Wales) will primarily target international students, both domestic and international students (from the region) are key to transnational enrollments. Equally, transnational enrollments are diverse by age. According to the Singapore Department of Statistics, about 35 percent of private-sector tertiary enrollments were aged 30 and over in 2003 , and perhaps another third were aged between 25 and 29. A government target of 60 percent cohort participation by 2010 and adult learning initiatives spurred by the proposed national open university will see longer term cohort decline offset by increased youth participation and a more active lifelong learning sector. Nonetheless, the Singapore higher education market is undoubtedly becoming more competitive.

\section{In June 2003, SIM offered 62 programs with for- eign universities, accounting for 12 percent of all registered transnational provision in Singapore and amounting to more foreign programs than offered by any other local partner.}

\section{Will Foreign Degrees Be Jettisoned?}

SIM is the most significant local partner for foreign providers. In June 2003, SIM offered 62 programs with foreign universities, accounting for 12 percent of all registered transnational provision in Singapore and amounting to more foreign programs than offered by any other local partner. Foreign partners include University of London External Program in the United Kingdom, Beijing University in China, RMIT University in Australia, and George Washington University in the United States. SIM also plays a major role in distance learning in Singapore. In 1992, the organization was appointed by the government to run the Open University Degree Program (to offer distance learning in collaboration with the U.K. Open University). The now named SIM Open University Centre has ambitions to become an independent open university in its own right and is the likely core of the announced national open university. According to the U.K. Open University, the SIM arrangement is the university's largest overseas collaboration, with over 1,000 students a year and over 4,000 graduates to date. It is not clear whether the Open University alliance is part of SIM's long-term plans, but degree-awarding powers and university title would be bound to undermine in the long term the value of transnational degree-awarding arrangements.

There are numerous private colleges and companies partnering with foreign universities to offer degrees in Singapore and most will not be in line for degree-awarding powers any time soon. But if leading providers such as SIM decide (or may be required) to jettison foreign degrees, then a significant portion of the current market will shift from transnational to domestic status. This scenario would also see some of the most experienced local partners exit the transnational market, leaving foreign institutions to develop new alliances with perhaps less competent organizations. Even if SIM and others opt to retain foreign programs in some form, it is highly likely that the number of foreign programs will be reduced in favor of a growing portfolio of in-house degrees.

In many ways, these changes are a natural process of development, and some transnational delivery is characterized by a steady extension of autonomy with a view to independence. But as a key market for leading transnational providers in Australia and the United Kingdom, the probable decline in demand for mainstream transnational delivery in Singapore over the next 10 years reinforces the need to explore new models and markets. The Singapore government clearly sees an ongoing role for elite foreign providers focusing on full branch campuses (INSEAD, Chicago, New South Wales) or niche R\&D (MIT, Technische Universität München), but for mainstream transnational delivery the "golden age" may be coming to an end.

\section{Universities: Family Style}

\section{Philip G. Altbach \\ Philip G. Altbach is Monan professor of higher education and director of the Center for International Higher Education at Boston College.}

A worldwide phenomenon in higher education that has been largely ignored is the ownership of private universities by families. While it is impossible to determine how many of these institutions exist, they certainly number at least in the hundreds and very likely many more. Some countries, such as Thailand, where half the private universities are family owned, have a large number. A few are respected high-status institutions that have existed for several generations, while many were recently established during the "higher education boom" of mass enrollments and do not rank at the top of the hierarchy.

The academic institutions in this category need to be examined because they are growing rapidly and although some have existed for a half century or more they are not well understood. 